WSRC-TR- $-90-521$

DE9 1005746

\title{
THE PHYSICAL PROPERTIES AND CHEMICAL. COMPOSITION OF THE GAS WITHIN THE FREE VOLUME OF CANISTERED WASTE FORMS (U)
}

\author{
J.R. Harbour, T.J. Miller, \\ and M.J. Whitaker
}

\section{Publication Date: November 1990}

\section{DISCLAIMER}

This report was prepared as an account of work sponsored by an agency of the United States Government. Neither the United States Government nor any agency thereof, nor any of their employees, makes any warranty, express or implied, or assumes any legal liability or responsibility for the accuracy, completeness, or usefulness of any information, apparatus, product, or process disclosed, or represents that its use would not infringe privately owned rights. Reference herein to any specific commercial product, process, or service by trade name, trademark, manufacturer, or otherwise does not necessarily constitute or imply its endorsement, recommendation, or favoring by the United States Government or any agency thereof. The views and opinions of authors expressed herein do not necessarily state or reflect those of the United States Government or any agency thereof.

\section{Westinghouse Savannah River Company} Savannah River Site Aiken, South Carolina 29808 


\section{THE DETERMINATION OF PRESSURE, DEWPOINT AND COMPOSITION OF THE GAS WITHIN THE FREE VOLUME OF CANISTERED WASTE FORMS. (U)}

\section{INTRODUCTION.}

The DWPF must meet Waste Acceptance Preliminary Specifications ${ }^{1}$ (WAPS) for acceptance of the DWPF canistered waste forms. A number of these specifications deal with the exclusion of non-wasteglass (or foreign) materials within the canistered waste forms. Those materials which are specifically excluded include the following:

- $\quad$ Free Liquids, WAPS 3.1

- $\quad$ Free Gases, other than cover or radiogenic gases, WAPS 3.2

- $\quad$ Explosives, Pyrophorics and Combustibles, WAPS 3.3

- $\quad$ Organics, WAPS 3.4

This report documents the results obtained by carrying out an assigned task ${ }^{2}$ as described in three task plans. ${ }^{3-5}$ These results provide evidence to demonstrate compliance with these specifications and will be included in the Waste Form Qualification Report (WQR).

In all, four canistered waste forms, produced during the Scale Glass Melter (SGM) campaigns, were examined. The internal gas pressure, dewpoint temperature and gas composition were determined for each canistered waste form. The experience gained in these experiments will be used to generate procedures for obtaining the same information on canistered waste forms produced during the Integrated Cold Runs (ICR).

\section{EXPERIMENTAL}

The experimental setup for canister penetration and sampling was designed and fabricated by EES. The requirements for this system were detailed in a Basic Data Report ${ }^{6}$. This was followed by a Scope of Work ${ }^{7}$ report from the Equipment Engineering Section (EES) which provided the details of design and fabrication of the canister penetration and sampling system. Schematics of the canister sampling system and the canister punch assembly are shown in Figures 1 and 2.

Each canister was drilled above the glass line as shown in Figure 2 such that approximately 40 mils of stainless steel (SS) remained. The drilling of the canisters was performed according to a procedure ${ }^{8}$ written by T. J. Miller. The wall thicknesses before and after drilling the four canisters are:

\begin{tabular}{ccc} 
CANISTER \# & INITIAL THICKNESS & EINAL THICKNESS \\
\hline A-6 & 0.410 inches & 0.042 inches \\
A-7 & 0.407 & 0.045 \\
A-16 & 0.405 & 0.040 \\
A-22 & 0.422 & 0.045
\end{tabular}

Two canisters originally specified to be a part of this study were not used. Canister A-4 was breached during the drilling stage and not used. Canister A-5, which was empty but 
sealed with a temporary seal, was evidently discarded. An additional canistered waste form, A-22, was added to the group to bring the total number of canisters characterized to four.

The next step was to weld a flange onto each canister centered around the predrilled hole (see Figure 2). The welding was done per SRS Welding Procedure 88-A. The welder was qualified per ASME Boiler and Pressure Vessel Code, Section IX.

The canister sampling system and the canister punch system were then ready for attachment. A procedure for canister penetration and sampli ig has been written ${ }^{9}$ and was followed during data acquisition on these four canisters. Part of this procedure is included in the Appendix.

For canister A-22, the pressure of the canister sampling system was less than $1 \mathrm{x}$ $10^{-4}$ Torr just prior to punching. The third blow from the hammer on the punch breached the canister as noted by a sudden increase in pressure. Several additional blows by the hammer increased the pressure to 735 Torr, a value which remained constant even after screwing the punch back out of the hole.

For canister A-22 a leak was found in the weld that attached the flange to the canister. This leak was remedied by applying a Dow Corning 3145 RTV adhesive Sealant to the welds. In any event, the application of this sealant with a subsequent 2 hour curing time (recommended on the sealant tube) allowed the system to be pumped down to a vacuum level below $10^{-4}$ Torr.

Of the four canisters used, three had temporary seals while only A-22 had a final seal (upset resistance welded). The leak rates measured for A-6 (on 5/24/88) and A-16 (on $5 / 31 / 88$ ) were $2.59 \times 10^{-5}$ and $1.25 \times 10^{-5} \mathrm{~atm} \cdot \mathrm{cc} / \mathrm{sec}$ respectively. The following table gives the weights and glass filling informition of the four canistered waste forms sampled.

$\begin{array}{cllll}\begin{array}{c}\text { Canister } \\ \#\end{array} & \begin{array}{l}\text { Weight } \\ \text { of Glass } \\ \text { lbs. }\end{array} & \begin{array}{l}\text { Weight } \\ \text { of Canister } \\ \text { lbs. }\end{array} & \begin{array}{l}\text { SGM } \\ \text { Campaign }\end{array} & \begin{array}{l}\text { Date Fill } \\ \text { Started }\end{array} \\ \text { A-6 } & 3986 & 1096 & 6-5 & 3 / 1 / 87 \\ \text { A-7 } & 4100 & 1100 & 6-7 & 3 / 6 / 87 \\ \text { A-16 } & 3668 & 1100 & 7-7 & - \\ \text { A-22 } & 3242 & 1110 & 2-3 & -\end{array}$

All of the Canisters were fabricated by Nooter Corporation and were made from 304L stainless steel using 308L stainless steel as a welding rod.

\section{Pressure Gauge}

An MKS Baratron Type 127A system with two pressure sensors (one sensor with a range from $10^{-4}$ to 1 Torr and another sensor with a range from 1 to 1000 Torr) was used for measurement of the pressure within this system. The lower range sensor was used to demonstrate that the pressure was less than 0.1 Torr after a designated 10 minute period in which the vacuum pump was valved off. If this was satisfied, the canister was breached (after repumping the system down) and the second sensor measured the pressure within the canister. These sensors were calibrated by E. C. Hill of the Standards Laboratory and the Certificates to this effect are part of the records package. 
The pressures recorded after canister penetration were the initial readings. The pressures changed slightly with time but these changes were always less than 1 Torr. The pressures were corrected for the expansion of the gas into the canister sampling system and in one case, the sample cylinder. The total volume of the canister sampling system without the sample cylinder was $7.4 \mathrm{in}^{3}$ or 0.12 liter. The volume of the canister sampling system plus the sample cylinder was $26.0 \mathrm{in}^{3}$ or 0.43 liter. These calculations are included in the final rezords package for this work. The correction was made assuming that the free volume of the canister was 140 liters. Hence the corrected pressure, $\mathrm{P}_{1}$ was calculated using Equation 1.

$$
\mathrm{P}_{1}=\mathrm{P}_{2}\left(\frac{\mathrm{V}_{2}}{\mathrm{~V}_{1}}\right)
$$

Where:

$$
\begin{aligned}
& \frac{V_{2}}{V_{1}} \text { for the canister sampling system }=\frac{140.12}{140}
\end{aligned}
$$

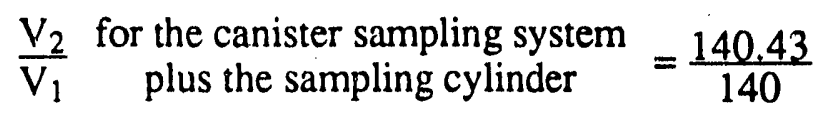

Only canister A-6 required this latter value since the sample cylinder valve was left open for this run. It was the only case where the corrected value was significant.

\section{Hygrometer}

A Panametrics System II Hygrometer was used to measure the dewpoint and the relative humidity of the air within the canister free volume space. This system was calibrated by Tritium Engineering and Technology (M\&TE1 No. EES\# 3-0143). The system was calibrated up to a dewpoint of $13.9^{\circ} \mathrm{C}$. Hence any dew points above this point would still read $13.9^{\circ} \mathrm{C}$. For these experiments all dew points were well below this value and therefore did not affect the outcome of any of the results. However, for the Integrated Cold Runs (ICR), it will be necessary to provide for a broader range of values in case a problem is encountered.

\section{Mass Spectrometer}

An Extrel Quadrupole Process Mass Spectrometer, Model Questor Series, was used to acquire data on the composition of the gas. Air was used as a "standard" for comparison with the gas inside the canister. The Questor operating manual (version 3.0, 1988) was followed during all experimerits.

To accomplish the connection between the canister sampling system and the mass spectrometer, it was necessary to run approximately 100 feet of stainless steel tubing from the ground floor, where the canisters were delivered, to the second floor where the mass spectrometer was located. This tubing had an outer diameter of $1 / 16$ " with an inner diameter of about $0.03 "$.

The system was checked with argon gas. One end of the tubing was placed into a beaker which was continually being purged with argon gas while the other end of the tubing was connected to the mass spectrometer. After the valve to the mass spectrometer was opened, argen was pumped through the line into the mass spectrometer. For 200 feet of the tubing, it took 6.5 minutes before the spectrum of argon first appeared. Afver 10 
minutes only the mass spectrum of argon was present. Due to a change in location of the canisters, only 100 feet of tubing was actually used. This reduced the amount of time required to deplete the tubing of gas.

Argon remained in the tubing until the first experiment (detection of air) was started. The transition from argon to air was complete within 5 minutes. This provided further evidence that the sampling system from the canister to the mass spectrometer was working properly.

In the first experiment, air was initially sampled in the laboratory in which the mass spectrometer is located. This was followed by sampling the air in the area where the canisters were located. The air from the room where the canisters are located was sampled through the 100 feet of stainless steel tubing to duplicate the path of the gas within the canister. Data acquisition using the mass spectrometer was accomplished using the following instructions:

\section{INSTRUCTIONS FOR DATA ACQUISITION BY MASS SPECTROMETER}

\section{SEQUENCE FOR DATA ACQUISITION ON EACH OF THE FOUR CANISTERS} (THE STORAGE ON DISK WILL BE FOR LAST TWO CANISTERS ONLY)

1. SCAN FROM 1 -200 MASS RANGE WITH FARADAY CUP DETECTOR WITHIN 1. MINUTE FROM THE TIME THAT THE MASS SPECTROMETER (MS) TUBING IS OPENED TO THE CANISTER SAMPLING SYSTEM(CSS). PLOT GRAPH ONLY

2. SCAN AGAIN FROM 1-200 MASS RANGE AT 5 MINUTES AFTER CSS AND MS ARE CONNECTED. PLOT GRAPH AND NUMBERS.

3. SCAN AGAIN FROM 1.200 MASS RANGE AT 10 MINUTES AFTER CSS AND MS ARE CONNECTED. PLOT GRAPH AND NUMBERS AND STORE DATA ON FLOPPY DISK.

4. SCAN FROM MASS RANGE 1-50 AND PLOT GRAPH.

5. SCAN FROM MASS RANGE 40 TO 90 AND PLOT GRAPH AND NUMBERS AND STORE DATA ON FLOPPY DISK.

6. SCAN FROM 90-200 MASS RANGE WITHOUT MULTIPLIER AND PLOT GRAPH AND NUMBERS AND STORE DATA ON FLOPPY DISK.

7. SCAN FROM 90-200 MASS RANGE WITH MULTIPLIER AT 1800 VOLTS AND PLOT GRAPH AND NUMBERS AND STORE DATA ON FLOPPY DISK.

\section{GENERAL INSTRUCTIONS}

- $\quad$ SAMPLE AIR FROM THE ROOM WITH MASS SPECTROMETER. TAKE A BROAD PLUS SEVERAL NARROW SPECTRA.

SAMPLE AIR FROM THE CSS BEFORE PUMP DOWN WITH MASS SPECTROMETER BY OPENING VALVE. TAKE A BROAD SPECTRUM AND THEN SEVERAL NARROWER AREAS AT HIGHER SENSITIVITY.

- $\quad$ NOTE PRESSURE DROP OF THE CSS AS SAMPLING CONTINUES.

- $\quad$ AT END OF THE SAMPLING OF THE FOUR CANISTERS, SAMPLE AIR FROM THE ROOM WITH MS. TAKE A BROAD PLUS SEVERAL NARROW SPECTRA. 
In addition to the data acquisition from the above, scans were made between 46 and 90 mass units and between 90 and 200 mass unirs with and without the multiplier. It turns out that the multiplier does provide for added sensitivity in both these cases. The mass spectrum without the multiplier gives only noise, whereas with the multiplier, signals are revealed. These signals are discussed in the Results and Discussion Section.

Standard gases were not used in this study since there were negligible differences between the mass spectrum of the gas within the canisters and air. There was a reduction in the amount of $\mathrm{CO}_{2}$ in the gas within the canisters (see Results and Discussion) but this result did not impact the purpose of this experiment which was to determine whether any additional components were present in the gas within the canisters.

It is possible to pump down the connecting tubing with the mass spectrometer pumping system while valve \#5 on the canister sampling system is closed. Then when mass spectral analysis of the gas is initiated by opening valve \#5, there is no back flow of air in the tubing (which may he at a higher pressure) into the canister sampling system. This is important since it will prevent contamination or dilution of the free volume gas which in turn is important since, after characterization by mass spectrometry, the sample tube is filled to provide a gas sample for potential future use. In the current experiments, the line was pumped down by the mass spectrometer for 2 hours for A-7, several minutes for A-16, and 5 hours for A-22. No prepumping was carried out with A-6.

\section{RESULTS AND DISCUSSION}

\section{Internal Canister Gas Pressure}

The internal gas pressure within the canisters was measured immediately after punching through the canisters. These values are:

\begin{tabular}{lcc} 
Canister \# & Pressure (Torr) & Corrected Pressure (Torr) \\
\hline A-6 & 734 & 736.3 \\
A-7 & 691 & 691.6 \\
A-16 & 721 & 721.6 \\
A-22 & 735 & 735.6
\end{tabular}

The ambient pressure reading (outside) prior to evacuation of the canister sampling system was taken in several cases and was very nearly $1 \mathrm{~atm}(760$ Torr). Hence in all cases the internal gas pressure within the canisters is less than atmospheric. This is consistent with the work of Langton ${ }^{10}$ where she demonstrated that three sealed canisters all had pressures less than 1 atmosphere (from 467 to 518 Torr). The fact that these canisters from the current experiments have pressures closer to atmospheric may result from the fact that the canisters were all filled two to three years ago and that leakage in the temporary seal may have occurred.

\section{MEASURED DEWPOINTS OF GAS WITHIN CANISTER}

The dewpoint temperature is that temperature at which the partial pressure of water vapor in a gas equals the saturation water vapor pressure. Below the dewpoint temperature, water 
will condense out whereas above this temperature no condensation will occur. The dewpoint temperatures measured using the hygrometer for each of the four canisters are:

$\begin{array}{ccc}\text { Canister \# } & \text { Initial Dewpoint } & \text { Final Dewpoint } \\ \text { A-6 } & -10.3^{\circ} \mathrm{C} & - \\ \text { A-7 } & +4.6^{\circ} \mathrm{C} & - \\ \text { A-16 } & +4.5 \mathrm{C} & +1.3^{\circ} \mathrm{C} \\ \text { A-22 } & +5.7^{\circ} \mathrm{C} & +4.0^{\circ} \mathrm{C}\end{array}$

The final dewpoint temperatures were taken the morning after the canisters were breached. The dewpoint temperatures for all four canisters decreased rapidly with time dropping $-5^{\circ} \mathrm{C}$ within 5 to 10 minutes. Since the canister sampling system was evacuated to pressures less than $1 \times 10^{-4}$ Torr, some of the adsorbed water on the inside surface of the system would be pumped off and collected in the liquid nitrogen trap. After canister penetration by the punch, the gas within the free volume of the canister expands into the canister sampling system. With time, water vapor within this gas adsorbs on the inside surface of the tubing leading to a lower value of the dewpoint temperature. For this reason, it is the initial dewpoint temperature which is considered most representative of the actual value.

Relative humidities (RH) were also measured foi each of these four canisters. The measurement of RH requires that the temperature of the system be known. The hygrometer has a temperature probe but it is not calibrated. However, the values we measured for temperature with this probe were very close to the temperatures received from the site. The values measured for temperature and $\mathrm{RH}$ in the system are:

$\begin{array}{lll}\text { Canister \# } & \text { RH } & \text { Temperat } \\ \text { A-6 } & & \\ \text { A-7 } & 5.5 \% & 29.5^{\circ} \mathrm{C} \\ \text { A-16 } & 13.4 & 33.7 \\ \text { A-22 } & 16.1 & 30.7 \\ & 18.5 & 31.8\end{array}$

The relative humidities also decreased with time similar to the time dependence of the dewpoint temperatures. The mechanism for this decrease is the same as that for the decrease in dewpoint temperature.

\section{GAS COMPOSITION}

The gas occupying the free volume of the canister was analyzed by mass spectrometry and the results are given in Table 1 . Three different air samples were measured for reference. The table gives the ratio of intensities of nitrogen (28) to oxygen (32), nitrogen to argon (40), nitrogen to carbon dioxide (44) and nitrogen to water(18). Since different molecules have different efficiencies in terms of generation of cation radicals from electron impact, these ratios are not equal to the relative amounts of the molecules. 


\section{TABLE 1}

\section{Gas Composition}

$\begin{array}{lllll}\text { SAMPLE } & \mathrm{N}_{2} / \mathrm{O}_{2} & \mathrm{~N}_{2} / \mathrm{AR} & \mathrm{N}_{2} / \mathrm{CO}_{2} & \mathrm{~N}_{2} / \mathrm{H}_{2} \mathrm{O} \\ \text { AIR 1 } & 4.13 & 25.24 & 198.2 & 19.26 \\ \text { AIR 2 } & 6.15 & 28.58 & 134.5 & 29.3 \\ \text { A-6 } & 4.23 & 25.02 & 301.8 & 37.35 \\ \text { A-7 } & 4.77 & 23.30 & 6300.8 & 43.82 \\ \text { A-16 } & 4.1 & 25.6 & 478.9 & 28.64 \\ \text { A-22 } & 4.26 & 23.85 & 318.1 & 22.3 \\ \text { AIR 3 } & 4.11 & 23.77 & 109.6 & 20.06\end{array}$

These results indicate that the ratio of nitrogen/oxygen and nitrogen/argon are effectively constant for the four canisters vs air. The water peak for the four canisters is generally less than that for air but depends critically on the history of air exposure to the 100 feet of connecting tubing. For this reason, the amount of water within the gas was measured using the hygrometer.

The carbon dioxide intensity, however, is consistently much less in the gas within the canisters than in the air. In fact for canister A-7, there is essentially no carbon dioxide left. For the other three canisters the intensity of carbon dioxide is $\sim 1 / 3$ that of air.

\section{OTHER SPECIES}

When the multiplier was used, three peaks emerged in the 90 to 190 mass range at 101,103 and 105 mass units. These three peaks were also present when the air was sampled through the 100 feet of stainless steel tubing and the canister sampling system. They were not present when the air was sampled through the mass spectrometer roon or through the tubing without the canister sampling system attached. This suggests that these peaks arise from the canister sampling system. This system was cleaned with an electroni: cleaner of trichlorotrifluoroethane. The observed fragments fit a $+\mathrm{CCl}_{2} \mathrm{~F}$ ion at 101 mass units with the 103 and 105 peaks due to the same fragment having one and two chlorine 37 isotopes. The relative intensities of these three peaks are also consistent with this assignment.

A peak at mass unit 48 was also evident when the multiplier was on. This peak has not been assigned but was present in the final air sample at roughly the same intensity. Hence it was not associated with the canistered waste form.

There was no evidence for hydrogen at mass unit of 2 . 


\section{CONCLUSIONS}

All four of the canistered waste forms tested in this study showed pressures less than atmospheric pressure. This is consistent with expectation and demonstrates that the internal pressure of the canister is less than 7 psig as required by the WAPS.

The dew points for all four canistered waste forms ranged from $-10.3^{\circ} \mathrm{C}$ to $+5.7^{\circ} \mathrm{C}$. These temperatures are much lower than the anticipated temperatures of 'Hot' canisters and consequently no condensation of water will occur during storage of the canistered waste forms at the DWPF glass waste storage facility. The relative humidities ranged from $5.5 \%$ to $18.5 \%$, consistent with the low dewpuint temperatures.

No foreign materials were observed in the gas phase of the canistered waste forms. The only ch inges noted using air as a reference was the decrease in carbon dioxide in the gas phase of the canistered waste forms. The reduction was a factor of three for three of the canisters and a factor of 50 for canister A-7. Hence there were no organics, pyrophorics, combustibles, or explosives present in the gas phase of these canistered waste forms.

From the data on dewpoints and characterization of the gas phase, it can be concluded that no volatile liquids are present in the canistered waste forms. This includes water, which if present, would have increased the relative humidity to $100 \%$. Other liquids, such as organics, would also have been detected by the mass spectrometer if present.

This system and procedures (witlı modifications as presented) are suitable for use in characterization of canistered waste forms produced during the Integrated Cold Runs. The results obtained from these experiments will also be used to demonstrate compliance with the WAPS.

\section{ACKNOWLEDGEMENTS}

Fred Sides, Mike Long, and H. O. Thornton provided the support and assistance to set up facilities at TNX for these experiments and ensured that the canisters were transported as required. Arnost Placr carried out the ultrasonic measurements for these experiments.

\section{REFERENCES}

1. Office of Civilian Radioactive Waste Management, Waste Acceptance Preliminary Specifications of the Defense Waste Processing Facility High-Level Waste Form, USDOE Report RW/0260, Revision 1, July, 1989 PE-03 (Formerly OGR/B-8).

2. "Comparibility of DWPF Canister and Contents, Task Assignment", WSRC-RP8319, (1989) M. J. Plodinec.

3. "R/D Task Plan: Determination of the Pressure and Gas Composition within SRL Canistered Waste Forms", WSRC-RP-89-1355 (1989) J. R. Harbour.

4. "R/D Task Plan: Determination of the Relative Humidities within SRL Canistered Waste Forms", WSRC-RP-89-1354 (1989) J. R. Harbour. 
5. "R/D Task Plan: Organic and Inorganic Analysis of Volatilized and Condensed Species Within SRL Canistered Waste Forms" WSRC-RP-90-179, (1990) J. R. Harbour and C. M. Jantzen.

6. "Basic Data Report, Canister Penetration System with Relative Humidity and Pressure Sensors", WSRC-RP-90-358 (1989) J. R. Harbour.

7. "Canister Penetration System, Scope of Work Report", EES 900097 (1990) T. J. Miller.

8. "Procedure for Drilling into a DWPF Canister for the Canister Penetration Project", EES Special Procedure No. 447, Rev. 1 (1990) T. J. Miller

9. "Procedure for Canister Penetration, Dewpoint and Pressure Measurements, and Connection to the Mass Spectrometer", GTOP-3-035 (1990) John R. Harbour.

10. . "Characterization of Internal Canister Environment during Interim Storage" DPST83-806, (1983) C. A. Langton. 
Figure 1. Canister Sampling System

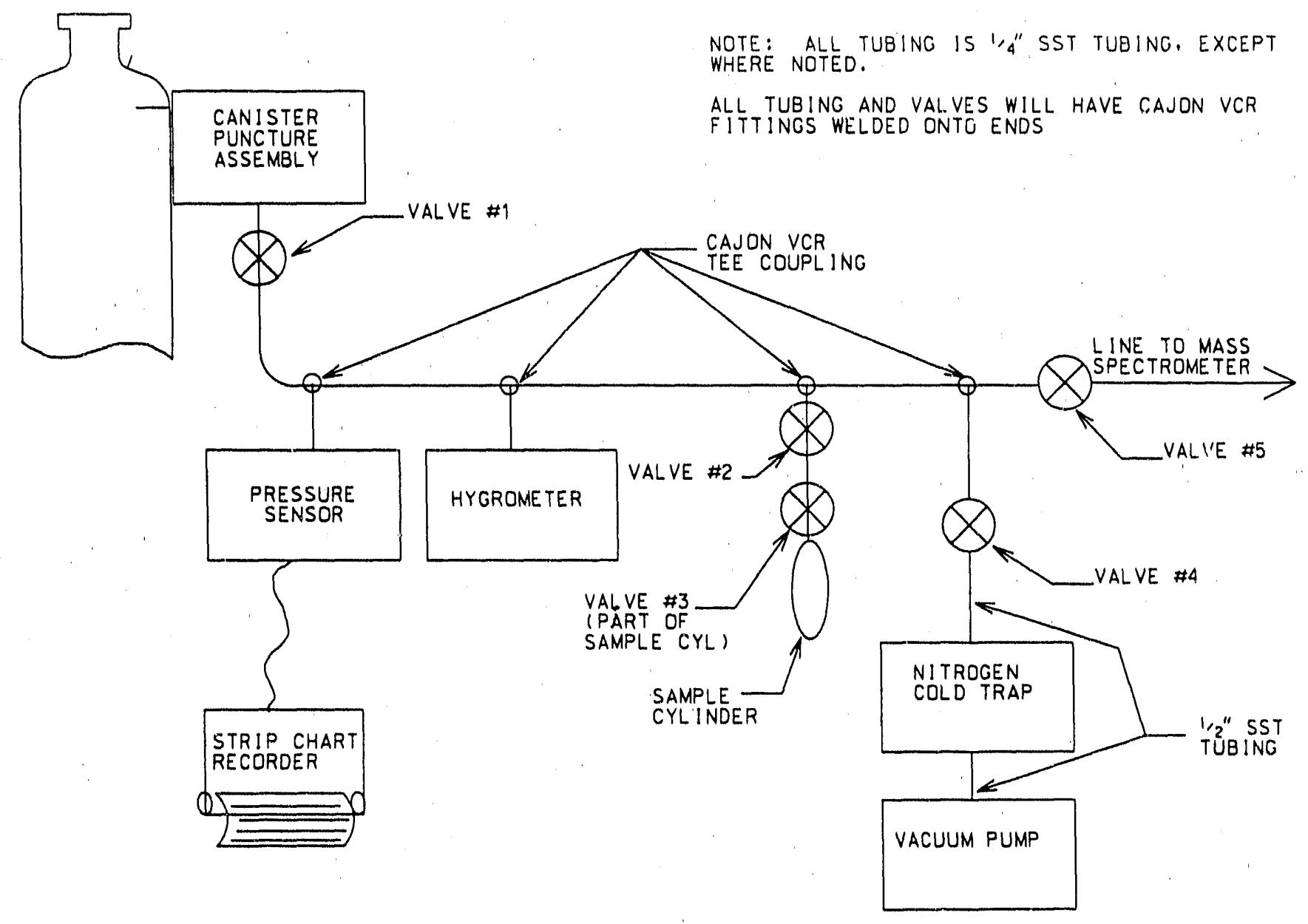


Figure 2. Punch Assembly Drawing

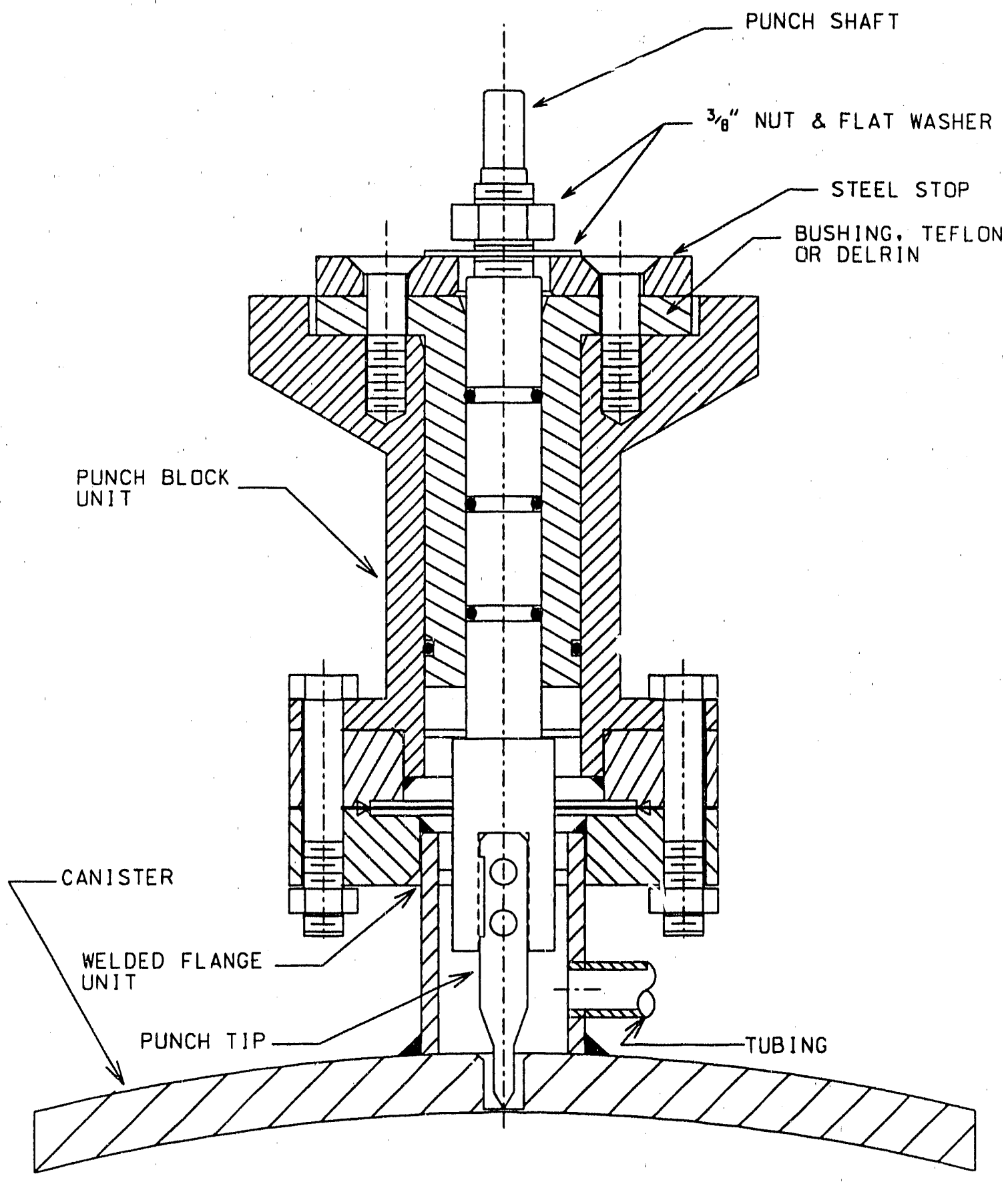




\section{APPENDIX}

\section{PROCEDURE FOR CANISTER PENETRATION, DEWPOINT AND PRESSURE MEASUREMENTS, AND CONNECTION TO THE MASS SPECTROMETER}

\subsection{PROCEDURE}

4.1 Clean each individual piece of tubing in the canister sampling system (CSS) shown in Attachment 2. This will be accomplished by using an electronic contact cleaner from Arcadia Chemical Company (a spray with a nozzle). The spray will be forced through the pieces until the liquid drips out from the other end. It will then be allowed to air dry. The hygrometer and pressure sensors will be used as received and will not be treated with contact cleaner. The pieces should be allowed to air dry for one i.cur.

4.2 Assemble or subassemble the CSS immediately after the one hour drying period as shown in Aitacl.ment 2. This may only have to be performed once at the beginning of the experiments provided the system is functioning properly. Temporarily seal off the ends with plastic caps until the time of canister sampling. The sample cylinder will have to be changed for each run.

\subsection{Ensure that all valves are closed.}

4.4 Make entry into data log sheet for each canister sampled:
A. Personnel involved in this experiment, noting the task leader.
B. Time and date.
C. Relative humidity outside.
D. Temperature outside.
E. Canister number which will be investigated.
F. Record M\&TE ID numbers and Manufacturer and model number for pressure sensor and hygrometer.

4.5 Clean welded-on flange and predrilled area. Use an electronic contact cleaner from Arcadia Chemical Company followed by complete drying with cotton swabs. Allow to dry for 5 minutes.

\subsection{Attach CSS to flange welded onto the canister.}

4.7 Clean each piece of the punch system with an elec'ronic contact cleaner from Arcadia Chemical Company and dry accordingly.

4.8 Assemble the top part of the punch assembly (the punch block unit) per Attachment 3. This may only have to be performed once at the beginning of the experiments provided the system is functioning properly. If vacuum grease is applied to the O-rings, record the type and brand-name in John R. Harbour's notebook. Be careful not to scratch the inside diameter of the bushing while inserting the punch shaft.

4.9 Place a copper gasket between the flanges of the flange welded unit and the punch block unit. Insert all 6 screws through the mating flanges and tighten to finger tightness. Torque the screw in $5 \mathrm{ft}-\mathrm{lb}$ increments in a star pattern to a final value of $10 \mathrm{ft}-\mathrm{lbs}$.

4.10 Ensure that the sample cell has the same number as the canister. 
4.11 Record this number for the sample cell in the log book and have the task leader initial.

4.12 Open valves $1,2,3$, and 4 and ensure that \#5 is closed.

4.13 Turn on the strip chart recorder, to begin acquisition of pressure and dewpoint data. This data will be used for reference cnly.

4.14 Turn vacuum pump on.

4.15 Immediately fill the Dewar/bucket around the cold trap with liquid nitrogen.

4.16 Continue pumping until system has stabilized at a pressure less than $1 \times 10^{-1}$ Torr.

4.17 Close valve \#4.

4.18 Record pressure, dewpoint, and time and have the task leader initial.

4.19 Monitor vacuum level for 10 minutes. If the pressure level remains $\leq 1 \times 10^{-1} \mathrm{Tom}$ licvel, go to step 4.21 . However, if the pressure level rises above the $1 \times 10^{-1}$ Torr level, then open valve \#4 and continue pumping for an additional 15 minutes; then reium to 4.17 .

4.20 In the event that this pressure level can not be maintained for 10 minutes and have the task leader initial and date the data log.

\subsection{Close valve \#2.}

4.23 Punch hole into canister. This will be accomplished by hitting the top of the punch with a hammer until penetration through the partially drilled hole occurs.

4.24 Extract punch tip from canister wall by jacking out punch shaft with the $3 / 8$ " nut.

4.25 Record time, pressure, dewpoint, temperature and relative humidity in data log and initial.

\subsection{Open valve \# 2 .}

4.27 Close valves \# 2 and 3.

4.28 The system is now ready for mass spectrometer data acquisition. This will be accomplished through a separate set of instructions and involves valve \$5.

4.29 After completion of the gas sampling with mass spectrometry, remove the sample cell ensuring that valves \#2 and 3 are indet d closed. Save this cell for future use as needed. 

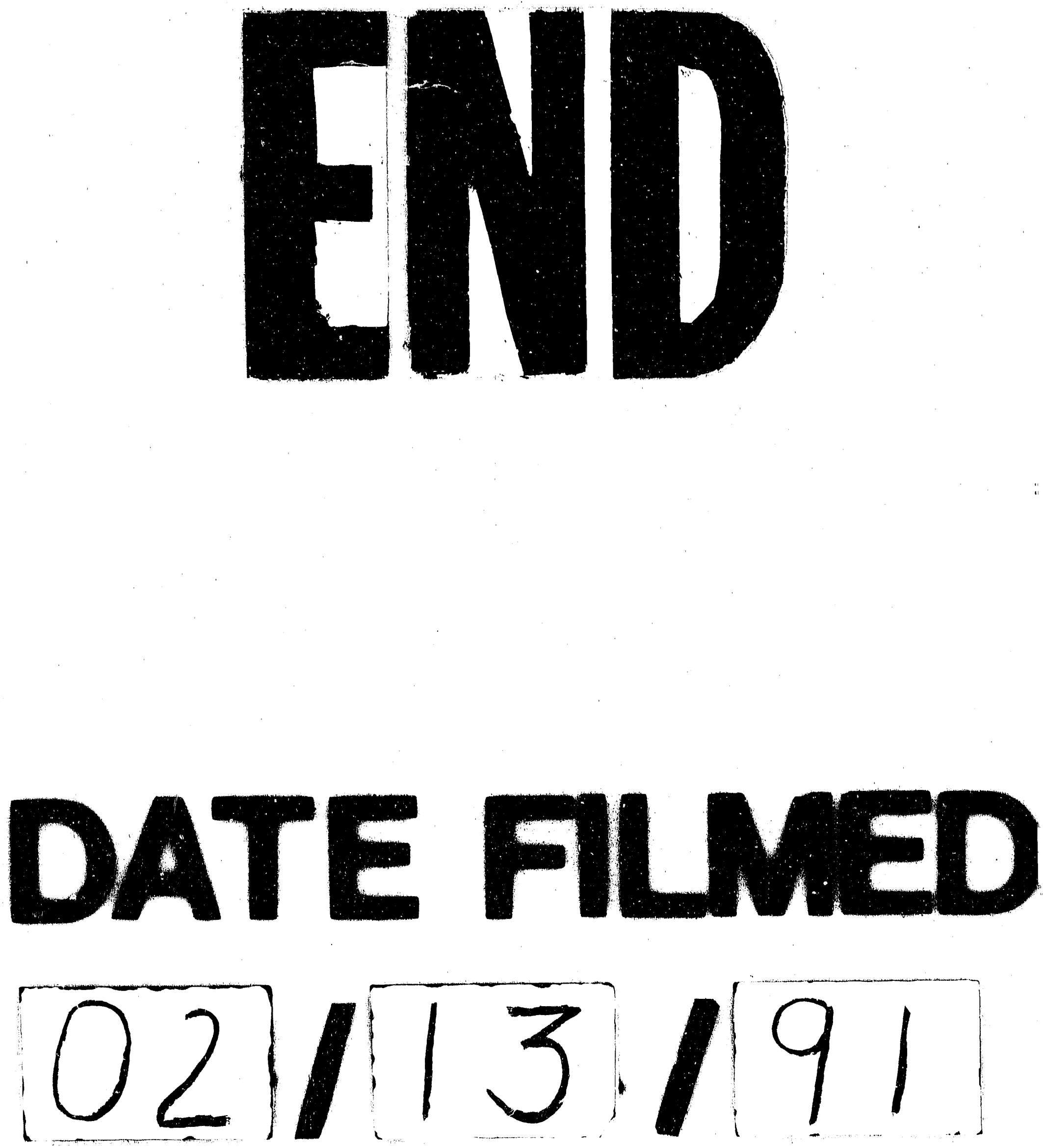
